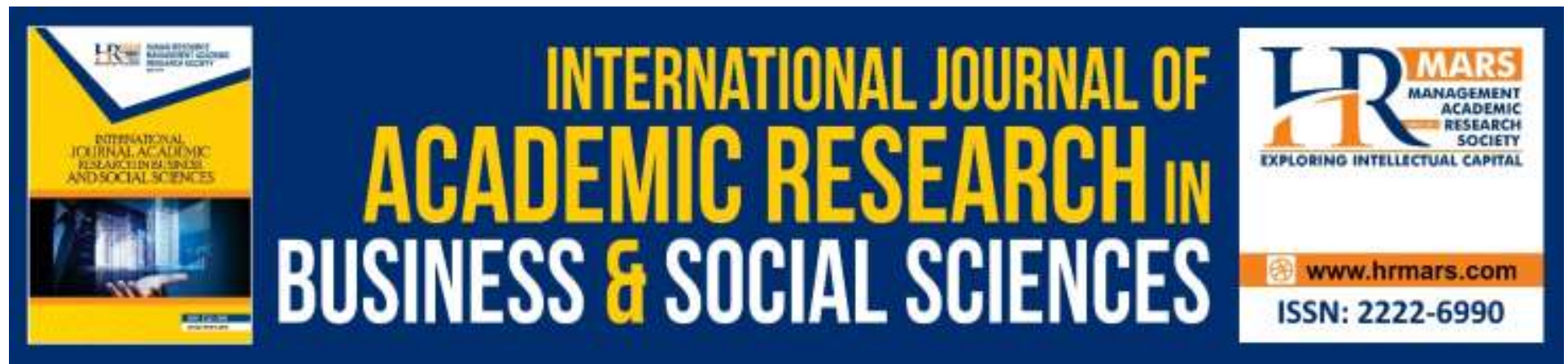

\title{
A Systematic Literature Review on Students Misconceptions in Mathematics
}

Noor Hidayah Jamaludin, Siti Mistima Maat

To Link this Article: http://dx.doi.org/10.6007/IJARBSS/v10-i6/7273

DOI:10.6007/IJARBSS/v10-i6/7273

Received: 10 April 2020, Revised: 15 May 2020, Accepted: 28 May 2020

Published Online: 09 June 2020

In-Text Citation: (Jamaludin \& Maat, 2020)

To Cite this Article: Jamaludin, N. H., \& Maat, S. M. (2020). A Systematic Literature Review on Students Misconceptions in Mathematics. International Journal of Academic Research in Business and Social Sciences, 10(6), 127-145.

\section{Copyright: (C) 2020 The Author(s)}

Published by Human Resource Management Academic Research Society (www.hrmars.com)

This article is published under the Creative Commons Attribution (CC BY 4.0) license. Anyone may reproduce, distribute, translate and create derivative works of this article (for both commercial and non-commercial purposes), subject to full attribution to the original publication and authors. The full terms of this license may be seen at: http://creativecommons.org/licences/by/4.0/legalcode

Vol. 10, No. 6, 2020, Pg. $127-145$

Full Terms \& Conditions of access and use can be found at http://hrmars.com/index.php/pages/detail/publication-ethics 


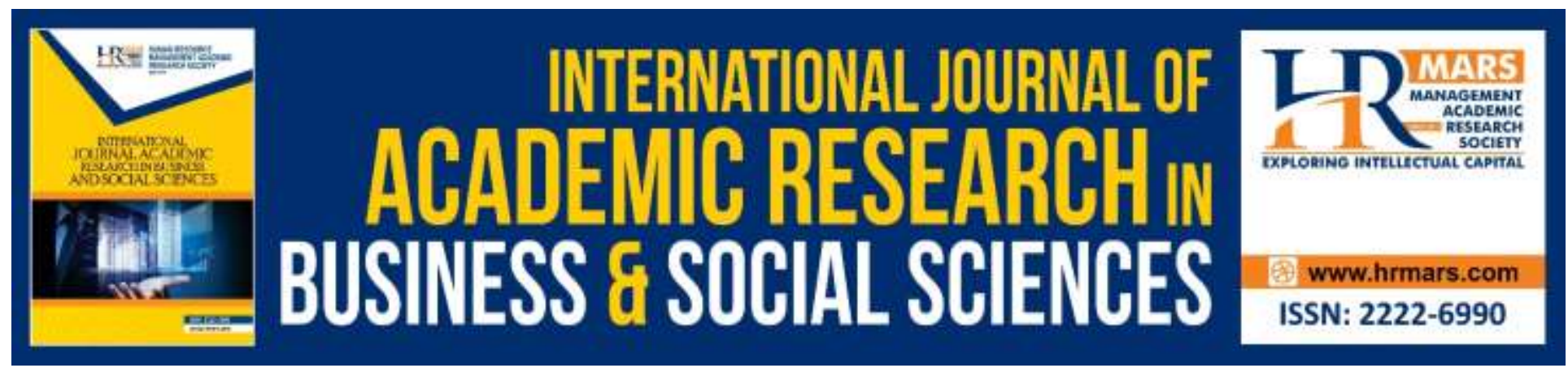

\title{
A Systematic Literature Review on Students Misconceptions in Mathematics
}

\author{
Noor Hidayah Jamaludin \\ Mathematics, Science and Computer, Politeknik Sultan Haji Ahmad Shah, 25350 Kuantan, \\ Pahang, Malaysia \\ Siti Mistima Maat \\ Research Centre of Teaching and Learning Innovations, Faculty of Education, Universiti \\ Kebangsaan Malaysia \\ Email: dayahj87@gmail.com, sitimistima@ukm.edu.my
}

\begin{abstract}
The misconception in mathematics education has been highlighted in various studies. However, there is still a limited literature review on students' misconceptions in mathematics. The purpose of this study is to review and analyze articles on student misconceptions in mathematics published between 2014 and 2019. The literature search for this study was conducted using four online databases, namely ERIC, Scopus, ScienceDirect, and Google Scholar. To ease the process, the researcher has set several inclusion and exclusion criteria before conducting the review. This study found that there is a decline in the number of articles published between 2014 to 2019 and that most studies have focused on primary school students. The study found that most of the studies conducted were aimed at determining misconceptions rather than overcoming students' misconceptions in mathematics education. Also, the instruments and methods for obtaining data that researchers often use are through tests and interviews. Some suggestions on overcoming misconceptions in mathematics are also highlighted for further study.
\end{abstract}

Keywords: Misconception, Mathematics, Misconception in Mathematics, Students.

\section{Introduction}

Mathematics is a subject that is always given special attention in schools. This is because mathematics is related to many other fields and disciplines. However, many students find it difficult to learn mathematics in school, and it is often considered as a difficult subject to learn. Acharya (2017) states that difficulties in learning mathematics are largely due to the fact that teachers do not associate new mathematics concepts with previously learned mathematical concepts, anxiety towards learning mathematics, negative perceptions towards mathematics, economic factors, students educational background, school management systems as well as the lack of infrastructure in schools and the absence of a continuous assessment system. Therefore, 
it is not surprising that many students consider mathematics as a challenging subject, and as a result, students have little interest in learning mathematics (Rohani et al., 2014).

Like most other subjects, students also make misconceptions in mathematics. According to Mohyuddin and Khalil (2014), mistakes and misconceptions occur when students make inappropriate generalizations about an idea. Nurul et al. (2019) further explained that students' failure to master the basic concepts of mathematics would increase their probability of using the wrong strategies, which in turn, result in errors and misconceptions in solving mathematical problems (Nurul et al., 2019). Based on this statement, it is believed that students should possess a strong mathematical foundation to help them learn mathematics effectively.

Studies like Siyepu (2015) highlighted that misconceptions stem from the early phase of learning, either in the classroom or as they interact socially with the world outside. It was described that mathematical knowledge is cumulative and is based on prior mathematical knowledge and learning (Siyepu, 2015; Sawardi \& Shahril, 2014). On the other hand, many students do realize the importance of prior information during the transition from school to higher learning. Such misconceptions can hinder the effectiveness of the teaching and learning process and affect students' mathematical achievement.

There are numerous studies on students' misconceptions in learning mathematics, which is focused on both local and international contexts. These studies include Sarwadi and Shahrill (2014), Yang and Lin (2015), Lin (2016), Trivena, Ningsih and Jupri (2017), Rakes and Ronau (2018), and Tabak (2019). Also, researchers have presented various definitions of misconceptions; Ojose (2015) defined misconceptions as misunderstandings that result from incorrect interpretations, while Korey and Bal (2002) pointed out that misconceptions constitute of wrong clarifications that most students accept as correct. Tippet (2010) further described that misconceptions are often used to illustrate beliefs that are incompatible with scientific explanations. Thus, misconceptions can be described as the differences of opinion between students and experts, where students' understanding produces systematic errors (Suprapto, 2013).

Although there are various definitions of misconceptions put forward by different researchers, many failed to distinguish between errors and misconceptions. Mistakes and misconceptions are related, but they are different as errors and students' negligence make mistakes. On the other hand, misconceptions are caused by students' misunderstandings, as they perceive they are right. This reflects the importance of distinguishing between errors and misconceptions in mathematical learning. Therefore, the most appropriate definitions of misconception and errors for this study are presented by Li, Julihi, and Eng (2017), who defined misconceptions as misunderstandings of ideas or concepts while errors reflect incorrect applications, concepts, theories, or formulas.

Studies by Eryilmaz (2002) mentioned that teachers need to identify and address common mathematical misconceptions among students to ensure the meaningfulness and effectiveness of mathematics lessons. Brodie (2014) argued that most misconceptions stem from incorrect previous knowledge. Ocal (2017) suggested that teachers should correct the misunderstandings of basic mathematical concepts before introducing a new concept. In this process, to avoid students from making the same mistakes, students need to be aware of the causes of the misconceptions and how to deal with them. In conclusion, determining misconceptions and 
identifying how to overcome misconceptions among students should be done continuously in making learning mathematics more meaningful.

\section{Methodology}

This study adopts the systematic literature review methodology, which involves reviewing previous studies on students' misconceptions in mathematics. This study follows the three phases proposed by Kithenham (2004). The phases involve: a) Phase 1: Planning the review, b) Phase 2: Conducting the review and c) Phase 3: Reporting the review

\section{Phase 1: Planning the review}

Preliminary searches started on September 17, 2019 using four databases, Google Scholar, Scopus, Education Resources Information Center (ERIC) and ScienceDirect. While the initial search found are many studies on the misconceptions in of mathematical concepts, there are limited number of studies that synthesized students' misconceptions in mathematics. Therefore, this study is important to fill this gap. As the purpose of this study is to conduct a retrospective review on studies synthesizing students' misconceptions in mathematics, the specific objectives of this study are as follow;

1. Who are the target group of the study?

2. What area of mathematics learning did the study focus on?

3. What is the main purpose for the study on misconception in mathematics?

4. What type of instruments or data source was used to determine misconceptions in mathematics?

According to Wohlin et al. (2012), the methods used to conduct a systematic literature review should demonstrate the search strategy, including searching online databases to find relevant studies, as well as the inclusion and exclusion criteria. The studies reviewed here were derived from four databases, ERIC, Scorpus, ScienceDirect and Google Scholar. The researcher has also set several inclusion and exclusion criteria to evaluate the quality of the studies derived from the databases. The inclusion criteria for this study are (i) studies that used the qualitative, quantitative or mixed method (ii) available in full text (iii) peer-reviewed journals, (iv) written in English, (v) published between 2014 and 2019, (vi) focused on misconceptions in mathematics and (vii) involved elementary, middle, high school and higher leaning students.

The initial phase involved searching the databases for relevant articles using the keyword "misconceptions" and found numerous articles on misconception. To further filter the articles, additional keywords were added to the search, along, with additional restrictions that the "misconceptions" prefix should be featured in the articles' title, abstract, or keyword. The researcher also added other keywords into the article search, which are "misconceptions" AND "mathematics", "students' misconceptions" and "students' misconceptions in mathematics". Moreover, the researcher excluded dissertations, book chapters, action research, proceedings papers and survey studies in the search process, as well as articles involving teachers as study participants. The inclusion and exclusion criteria were set at the beginning of the study to ensure the study's focus is clear and directed. 


\section{Phase 2: Conducting the review}

This study aims to find and review research articles focusing on misconceptions in mathematics. This study reviewed articles published on misconception in mathematics education, and articles indexed in the selected databases were analyzed to obtain data on misconceptions in mathematics. Systematic searches were conducted starting on September 20, 2019 to identify related articles in four online databases namely ERIC, Scopus, ScienceDirect and Google Scholar. This study only reviewed research articles written in English which were published between 2014 and 2019.

The first step involved finding relevant articles in the database, which highlighted the specified keywords in their title or abstract. An initial search found 453 articles. It was found while the initial search found many articles; many of them are not relevant to the main topic. 30 redundant articles were excluded and subsequently, the inclusion criteria were narrowed down to ensure only the appropriate articles were retrieved. Therefore, articles that do not have the word "misconceptions" in the keyword section and are not related to mathematic education were excluded. Thus, out of 453 articles found during the initial search, only 30 study articles published between 2014 and 2019 were retained for the review. The flow for the search process and the selection of articles for this review is illustrated in Figure 1.

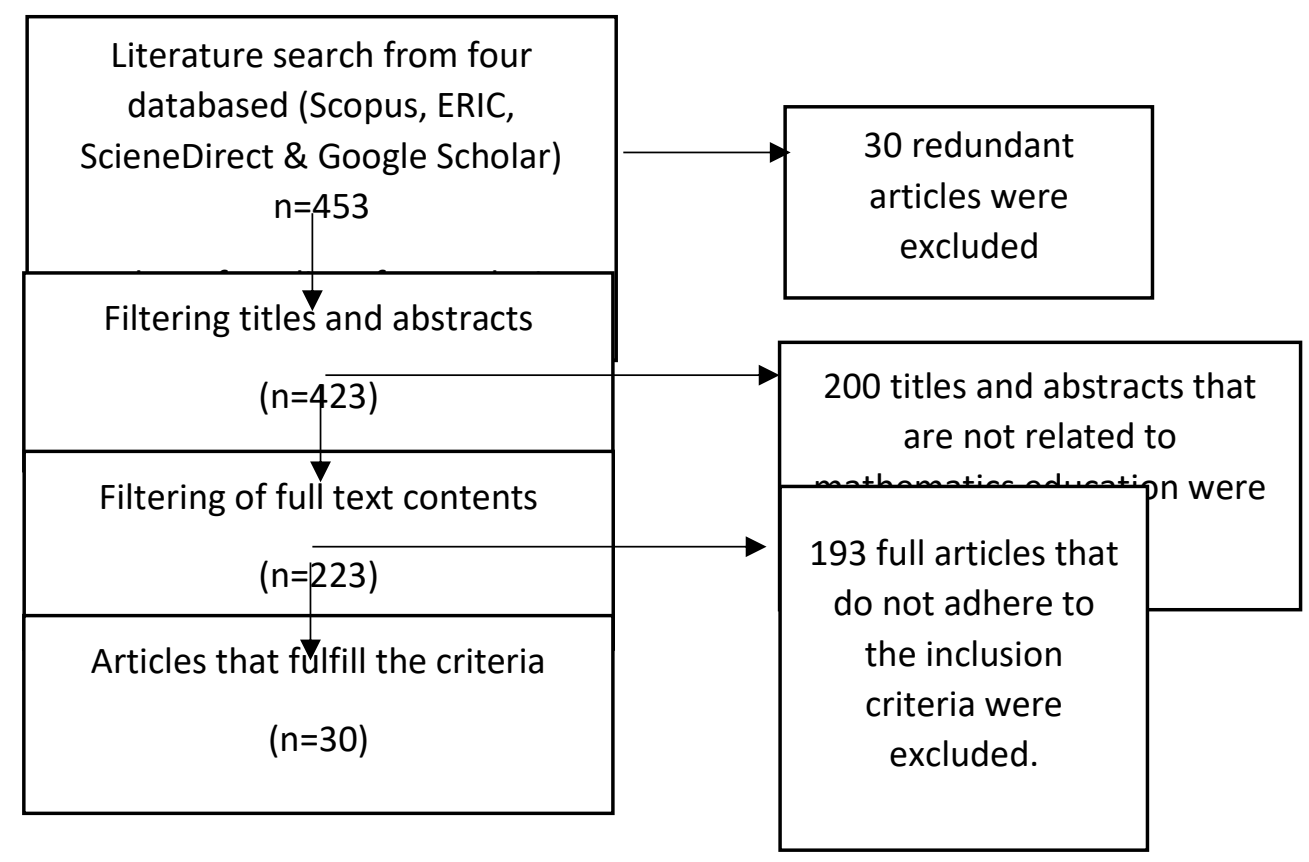

Figure 1: The flow of the search and article selection process

\section{Phase 3: Reporting the Review}

Each article that adheres to the specified inclusion criteria is listed in Table 1 which details the name of the article's author (s), year of publishing, study area, study participant, study method, instrument or source, and whether the study was conducted to identify misconception or to overcome misconception. 
INTERNATIONAL JOURNAL OF ACADEMIC RESEARCH IN BUSINESS AND SOCIAL SCIENCES

Vol. 10, No. 6, June, 2020, E-ISSN: 2222-6990 @ 2020 HRMARS

Table 1. List of students' misconceptions in mathematics according to the inclusion criteria

\begin{tabular}{|c|c|c|c|c|c|}
\hline Author/ year & Study area & $\begin{array}{l}\text { Participants' } \\
\text { level of study }\end{array}$ & Method & Instrument/ source & Main purpose \\
\hline $\begin{array}{l}\text { Gningue, Menil \& } \\
\text { Fuchs (2014) }\end{array}$ & Algebra & College students & Mixed method & $\begin{array}{l}\text { Pre-algebra test, final exam, } \\
\text { interview, 24-question Likert } \\
\text { scale survey }\end{array}$ & $\begin{array}{l}\text { Overcoming } \\
\text { misconception }\end{array}$ \\
\hline $\begin{array}{l}\text { Durkin \& Rittle- } \\
\text { Johnson (2015) }\end{array}$ & Numbers & $\begin{array}{l}\text { Primary school } \\
\text { students }\end{array}$ & Quantitative & Survey & $\begin{array}{l}\text { Determining } \\
\text { misconception }\end{array}$ \\
\hline $\begin{array}{l}\text { Kula \& Guzel } \\
\text { (2014) }\end{array}$ & Limit & $\begin{array}{l}\text { In service } \\
\text { student teacher } \\
\text { (Mathematics } \\
\text { student teacher) }\end{array}$ & Qualitative & $\begin{array}{l}\text { Lesson plans, video recordings } \\
\text { of the participants' lessons and } \\
\text { audio recordings of semi- } \\
\text { structured interviews }\end{array}$ & $\begin{array}{l}\text { Determining } \\
\text { misconception }\end{array}$ \\
\hline $\operatorname{Lin}(2016)$ & Numbers & $\begin{array}{l}\text { Primary school } \\
\text { students }\end{array}$ & Quantitative & $\begin{array}{l}50 \text { web-based two-tier } \\
\text { diagnostic test items (WTTT- } \\
\text { NS) }\end{array}$ & $\begin{array}{l}\text { Determining } \\
\text { misconception }\end{array}$ \\
\hline $\begin{array}{l}\text { Makonye \& } \\
\text { Fakude (2016) }\end{array}$ & Numbers & $\begin{array}{l}\text { Primary school } \\
\text { students }\end{array}$ & Qualitative & $\begin{array}{l}\text { Addition and subtraction } \\
\text { assignments from student } \\
\text { training books and interviews }\end{array}$ & $\begin{array}{l}\text { Determining } \\
\text { misconception }\end{array}$ \\
\hline $\begin{array}{l}\text { Ozkan \& Bal } \\
\text { (2017) }\end{array}$ & Geometry & $\begin{array}{l}\text { Primary school } \\
\text { students }\end{array}$ & Quantitative & Diagnostic test & $\begin{array}{l}\text { Determining } \\
\text { misconception }\end{array}$ \\
\hline
\end{tabular}


INTERNATIONAL JOURNAL OF ACADEMIC RESEARCH IN BUSINESS AND SOCIAL SCIENCES

Vol. 10, No. 6, June, 2020, E-ISSN: 2222-6990 @ 2020 HRMARS

\begin{tabular}{|c|c|c|c|c|c|}
\hline $\begin{array}{l}\text { Dhlamini \& } \\
\text { Kibirige (2014) }\end{array}$ & Fractions & $\begin{array}{l}\text { Primary school } \\
\text { students }\end{array}$ & Qualitative & $\begin{array}{l}\text { Mathematical task and semi } \\
\text { structured interviews }\end{array}$ & $\begin{array}{l}\text { Determining } \\
\text { misconception }\end{array}$ \\
\hline Uzel (2018) & Fractions & $\begin{array}{l}\text { Primary school } \\
\text { students }\end{array}$ & Quantitative & Survey & $\begin{array}{l}\text { Determining } \\
\text { misconception }\end{array}$ \\
\hline Tabak (2019) & $\begin{array}{l}\text { Arithmetic } \\
\text { expressions }\end{array}$ & $\begin{array}{l}\text { Secondary school } \\
\text { students }\end{array}$ & Mixed method & Two-tier diagnostic test & $\begin{array}{l}\text { Determining } \\
\text { misconception }\end{array}$ \\
\hline $\begin{array}{l}\text { Aliustaoğlu, Tuna } \\
\text { \& Biber (2018) }\end{array}$ & Fractions & $\begin{array}{l}\text { Secondary school } \\
\text { students }\end{array}$ & Qualitative & $\begin{array}{l}\text { Fractional information test, } \\
\text { which consists of } 5 \text { open- } \\
\text { ended questions }\end{array}$ & $\begin{array}{l}\text { Determining } \\
\text { misconception }\end{array}$ \\
\hline Machaba (2016) & $\begin{array}{l}\text { Area and } \\
\text { perimeter }\end{array}$ & $\begin{array}{l}\text { Secondary school } \\
\text { students }\end{array}$ & Qualitative & Written test and interviews & $\begin{array}{l}\text { Determining } \\
\text { misconception }\end{array}$ \\
\hline Oçal (2017) & Functions & $\begin{array}{l}\text { University } \\
\text { students }\end{array}$ & Qualitative & $\begin{array}{l}\text { Students graphs sketched and } \\
\text { interviews }\end{array}$ & $\begin{array}{l}\text { Overcoming } \\
\text { misconception }\end{array}$ \\
\hline $\begin{array}{l}\text { Fadillah \& Susiaty } \\
\text { (2019) }\end{array}$ & Integers & $\begin{array}{l}\text { Primary school } \\
\text { students }\end{array}$ & Qualitative & $\begin{array}{l}\text { The development of } \\
\text { refutation text incorporated } \\
\text { the development model, } \\
\text { interviews and refutation text } \\
\text { test }\end{array}$ & $\begin{array}{l}\text { Overcoming } \\
\text { misconception }\end{array}$ \\
\hline
\end{tabular}


INTERNATIONAL JOURNAL OF ACADEMIC RESEARCH IN BUSINESS AND SOCIAL SCIENCES

Vol. 10, No. 6, June, 2020, E-ISSN: 2222-6990 @ 2020 HRMARS

\begin{tabular}{|c|c|c|c|c|c|}
\hline $\begin{array}{l}\text { Alghazo \& } \\
\text { Alghazo (2017) }\end{array}$ & Fractions & College students & Quantitative & $\begin{array}{l}\text { Mathematical test and } \\
\text { interviews }\end{array}$ & $\begin{array}{l}\text { Determining } \\
\text { misconception }\end{array}$ \\
\hline Stavrou (2014) & Number Theory & $\begin{array}{l}\text { Undergraduate } \\
\text { students }\end{array}$ & Qualitative & $\begin{array}{l}\text { Analysis of students' } \\
\text { assignment }\end{array}$ & $\begin{array}{l}\text { Determining } \\
\text { misconception }\end{array}$ \\
\hline $\begin{array}{l}\text { Rakes \& Ronau } \\
\text { (2018) }\end{array}$ & $\begin{array}{l}\text { Algebra, } \\
\text { geometry, rational } \\
\text { number and } \\
\text { probability }\end{array}$ & $\begin{array}{l}\text { Secondary school } \\
\text { students }\end{array}$ & Mixed method & $\begin{array}{l}17 \text { multiple choice items from } \\
\text { the National Assessment of } \\
\text { Educational Progress and } \\
\text { interviews }\end{array}$ & $\begin{array}{l}\text { Determining } \\
\text { misconception }\end{array}$ \\
\hline $\begin{array}{l}\text { Sarımanoğlu } \\
\text { (2019) }\end{array}$ & Algebra & $\begin{array}{l}\text { Secondary school } \\
\text { students }\end{array}$ & Qualitative & $\begin{array}{l}\text { Question sheet and semi- } \\
\text { structured interviews }\end{array}$ & $\begin{array}{l}\text { Determining } \\
\text { misconception }\end{array}$ \\
\hline $\begin{array}{l}\text { Li, Julaihi \& Eng } \\
\text { (2017) }\end{array}$ & Integrals & $\begin{array}{l}\text { University } \\
\text { students }\end{array}$ & Mixed method & $\begin{array}{l}\text { Students work solution in } \\
\text { calculus exam and interviews }\end{array}$ & $\begin{array}{l}\text { Determining } \\
\text { misconception }\end{array}$ \\
\hline $\begin{array}{l}\text { Tiwari \& Fatima } \\
\text { (2019) }\end{array}$ & Algebra & $\begin{array}{l}\text { Secondary school } \\
\text { students }\end{array}$ & Mixed method & Algebra test and interviews & $\begin{array}{l}\text { Determining } \\
\text { misconception }\end{array}$ \\
\hline $\begin{array}{l}\text { Trivena, Ningsih } \\
\text { \& Jupri (2017) }\end{array}$ & Fractions & $\begin{array}{l}\text { Primary school } \\
\text { students }\end{array}$ & Qualitative & $\begin{array}{l}5 \text { items of multiple choice test } \\
\text { questions and interviews }\end{array}$ & $\begin{array}{l}\text { Determining } \\
\text { misconception }\end{array}$ \\
\hline $\begin{array}{l}\text { Ang \& Shahrill } \\
(2014)\end{array}$ & Probability & $\begin{array}{l}\text { Secondary school } \\
\text { students }\end{array}$ & Quantitative & $\begin{array}{l}\text { Two-tier questionnaire survey } \\
\text { and interviews }\end{array}$ & $\begin{array}{l}\text { Determining } \\
\text { misconception }\end{array}$ \\
\hline $\begin{array}{l}\text { Mehmetlioğlu } \\
(2014)\end{array}$ & Numbers & $\begin{array}{l}\text { Primary school } \\
\text { students }\end{array}$ & Quantitative & Decimal Comparison Test & $\begin{array}{l}\text { Determining } \\
\text { misconception }\end{array}$ \\
\hline
\end{tabular}


INTERNATIONAL JOURNAL OF ACADEMIC RESEARCH IN BUSINESS AND SOCIAL SCIENCES

Vol. 10, No. 6, June, 2020, E-ISSN: 2222-6990 @ 2020 HRMARS

$\begin{array}{lll}\begin{array}{l}\text { Sisman \& Aksu } \\ (2016)\end{array} & \begin{array}{l}\text { Length, area and } \\ \text { volume }\end{array} & \begin{array}{l}\text { Primary school } \\ \text { students }\end{array}\end{array}$ Quantitative

16 constructed-response

format tasks prepared based

Determining on previous research

misconception

The algebraic Misconceptions

Lin, Ko \& Kuo

(2014)

Algebra

Pre service

teachers

Quantitative

Test (AMT) and The Attitudes

Toward Computers and

Mathematics Teaching

Determining

Questionnaire (ATCMT)

Turnuklu (2014)

Quadrilaterals

Pre service
teachers

Qualitative

Lesson plans which were

prepared by pre service

teachers

Determining misconception

crach


INTERNATIONAL JOURNAL OF ACADEMIC RESEARCH IN BUSINESS AND SOCIAL SCIENCES

Vol. 10, No. 6, June, 2020, E-ISSN: 2222-6990 @ 2020 HRMARS

\section{Results}

The articles obtained during the analysis process were analyzed. Based on the findings, the results obtained are organized into five sections:
a) The trend of literature on the misconceptions in mathematics
b) Target participants
c) Mathematics concept being focused by the study
d) The main purpose of the study.
e) Instruments/methods used to determine misconceptions in mathematics

\section{The Trend of Literature on the Misconceptions in Mathematics}

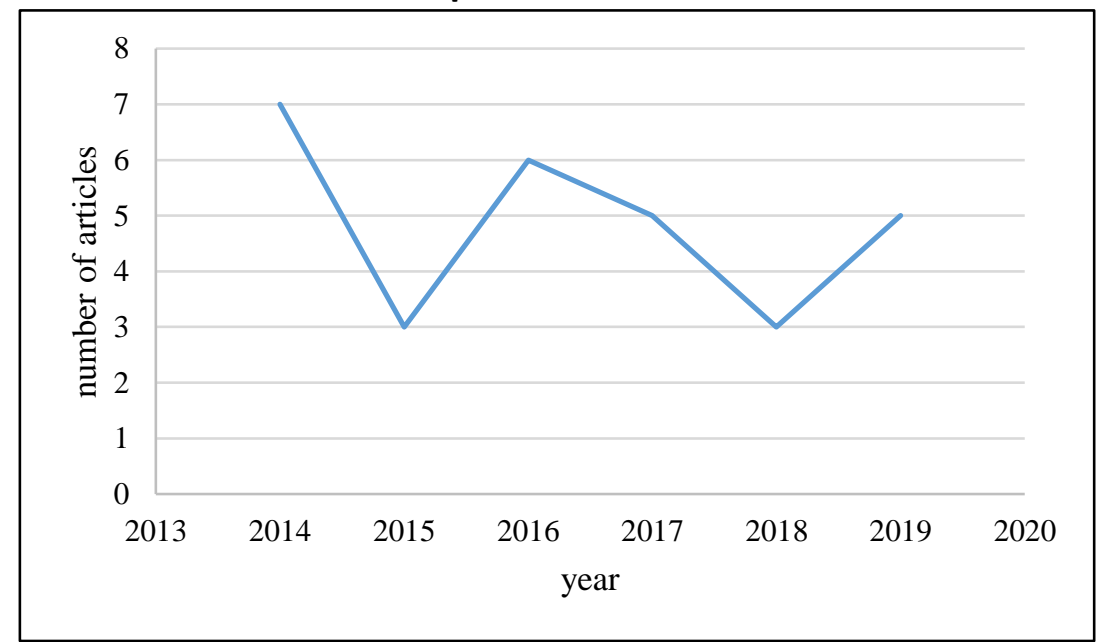

Figure 2: Number of articles published between 2014 and 2019

Figure 2 shows the number of articles related to misconceptions in mathematics education published between 2014 and 2019. In all, there are 30 articles analyzed. It could be observed that there is a decrease in the number of articles published on misconceptions in mathematics from 2014 to 2015. However, there is a positive trend in the number of articles published between 2015 and 2016 with a $50 \%$ increase in the number of articles. However, the number declined from 2016 to 2018, but it increased again between 2018 to 2019. Therefore, it can be said that overall, the number of published articles in this period is significantly lower compared to the number of articles published in 2014. 
INTERNATIONAL JOURNAL OF ACADEMIC RESEARCH IN BUSINESS AND SOCIAL SCIENCES

Vol. 10, No. 6, June, 2020, E-ISSN: 2222-6990 @ 2020 HRMARS

\section{Target Participants}

Table 2. The target participants of the published research articles reviewed

\begin{tabular}{llc}
\hline Category of participants & Total \\
\hline School students & Primary & 15 \\
& Secondary & 5 \\
Higher learning & University & 5 \\
& College & 2 \\
& Pre-service teachers & 2 \\
& In service student teachers & 1 \\
\hline Total & & 30 \\
\hline
\end{tabular}

Table 2 presents the target participants of the published research articles reviewed. It was found that the studies focused on students from various levels of education, including primary, secondary as well as higher learning students (university and college students, pre-service teachers, and in-service student teachers). Table 2 shows that the study's participants can be categorized into two types, which were students and higher learning students. School students include primary and secondary schools, while higher learning students include undergraduate (university and college) students, preservice teachers and in-service postgraduate students. The majority (20) of the studies involved school students, predominantly primary school students, and only 10 studies involved students in higher learning. This indicates that the research on misconceptions in mathematics education has primarily focused on students in the lower/elementary level, and less attention has been given to misconception among graduate students. This reflects the need to conduct studies on students from different educational levels to illustrate students' misconceptions in mathematics at various levels.

\section{Areas of Focus}

Another aspect being considered in this review is the area being focused on the studies. The initial review found that these studies have focused on diverse mathematical areas. Table 3 presents the categories of areas being discussed in previous articles. 
INTERNATIONAL JOURNAL OF ACADEMIC RESEARCH IN BUSINESS AND SOCIAL SCIENCES Vol. 10, No. 6, June, 2020, E-ISSN: 2222-6990 @ 2020 HRMARS

Table 3. The areas of mathematical learning being focused in the studies

\begin{tabular}{llc}
\hline Category & Mathematics area & Quantity \\
\hline An area, $\mathbf{n = 2 7}$ & Algebra & 4 \\
& Numbers & 5 \\
& Limit & 3 \\
& Geometry & 2 \\
& Fractions & 5 \\
& Functions & 1 \\
& Integers & 1 \\
& Number theory & 1 \\
& Arithmetic expressions & 1 \\
& Integrals & 1 \\
& Differential equations & 1 \\
& Quadrilaterals & 1 \\
& Probability & 1 \\
More than one area, $\mathbf{n = 3}$ & Area and perimeters & 1 \\
& Algebra, geometry, rational number and & 1 \\
& probability & 1 \\
\hline
\end{tabular}

Table 3 shows that the most studied area is numbers (Durkin \& Rittle-Johnson, 2015; Lin, 2016; Yang \& Lin, 2015; Makonye \& Faculty, 2016; Alghazo \& Alghazo, 2017), and fractions (Dhlamini \& Kibirige., 2014; Uzel, 2018; Aliustaoglu, Tuna \& Biber, 2018; Sarwadi, \& Shahrill, 2014; Trivena, Ningsih \& Jupri, 2017) with a total of 5 articles for each respective area. Other areas being focused on are limit (Kula \& Guzel, 2014; Winarso, 2017; Denbel, 2014), geometry (Ozkan \& Bal, 2017; Luneta, 2015), functions (Oçal, 2017), integers (Fadillah \& Susiaty, 2019), number theory (Stavrou, 2014), algebra (Lin \& Kuo, 2014; Gningue, Menil, \& Fuchs, 2014; Sarımanoğlu , 2019; Tiwari \& Fatima, 2019), integrals (Li, Julihi, \& Eng 2017), differential equations (Ming, Foong \& Ng, 2017), quadrilateral (Turnuklu, 2014), and probability (Ang \& Shahrill, 2014).

Some studies focused on in more than one area of mathematical learning, such as area and perimeters (Machaba, 2016), algebra, geometry, number and probability (Rakes \& Ronau, 2018), as well as length, area and volume (Sisman \& Aksu, 2016). However, most studies only focused on only one field.

\section{Purpose of studies}

In general, the primary purpose of these studies can be categorized into two, either to determine the type of mathematical misconception or to address and overcome mathematical misconceptions. Table 4 presents the main purpose of previous studies on student misconceptions in mathematics. 
INTERNATIONAL JOURNAL OF ACADEMIC RESEARCH IN BUSINESS AND SOCIAL SCIENCES Vol. 10, No. 6, June, 2020, E-ISSN: 2222-6990 @ 2020 HRMARS

Table 4. The main purpose of the studies on the misconception in mathematics

\begin{tabular}{|c|c|}
\hline The main purpose of studies & Author (Year) \\
\hline \multirow[t]{27}{*}{ Determining misconception, $n=27$} & Durkin \& Rittle-Johnson (2015) \\
\hline & Kula \& Guzel (2014) \\
\hline & $\operatorname{Lin}(2016)$ \\
\hline & Yang \& Lin (2015) \\
\hline & Makonye \& Fakude (2016) \\
\hline & Ozkan \& Bal (2017) \\
\hline & Dhlamini \& Kibirige (2014) \\
\hline & Uzel (2018) \\
\hline & Tabak (2019) \\
\hline & Aliustaoglu, Tuna \& Biber (2018) \\
\hline & Machaba (2016) \\
\hline & Luneta (2015) \\
\hline & Winarso (2017) \\
\hline & Alghazo \& Alghazo (2017) \\
\hline & Stavrou (2014) \\
\hline & Rakes \& Ronau (2018) \\
\hline & Sarımanoglu (2019) \\
\hline & Li, Julaihi \& Eng (2017) \\
\hline & Denbel (2014) \\
\hline & Ming, Eng, Foong \& Ng (2017) \\
\hline & Tiwari \& Fatima (2019) \\
\hline & Trivena, Ningsih \& Jupri (2017) \\
\hline & Ang \& Shahrill (2014) \\
\hline & Mehmetlioglu (2014) \\
\hline & Sisman \& Aksu (2016) \\
\hline & Lin, Ko \& Kuo (2014) \\
\hline & Turnuklu (2014) \\
\hline \multirow[t]{3}{*}{ Overcoming misconception, $n=3$} & Gningue, Menil \& Fuchs (2014) \\
\hline & Ocal (2017) \\
\hline & Fadillah \& Susiaty (2019) \\
\hline
\end{tabular}

Based on the analysis conducted, it can be said that overall, most of the previous studies were conducted to determine the type of misconception that occurs among students. However, three studies focused on overcoming misconceptions among students (Gningue, Menil \& Fuchs, 2014; Oçal, 
2017; Fadillah \& Susiaty, 2019). A study conducted by Gningue, Menil and Fuchs (2014) compared the effects of teaching the concepts of pre-algebra and algebra using a virtual manipulation module and through the traditional methods. The findings show that virtual manipulation can help students to overcome misconceptions about algebra and pre-algebra concepts. Another study by Ocal (2017) examined whether the use of the GeoGebra application allows students to determine and solve misconceptions in calculus classes. The students were divided into treatment groups and control groups and comparisons were made between the misconceptions demonstrated by the students in both groups in drawing basic function graphs of $\frac{1}{x}, \ln x$ dan $e^{x}$. Ocal's (2017) study suggested that students who were taught using GeoGebra can draw functions graphs better. Furthermore, the study conducted by Fadillah and Susiaty (2019) showed that refutation text used by students in the pilot classes has been effective to overcome the students' misconceptions in solving addition and subtraction problems, and the approach can be used as a learning medium to overcome students' misconceptions.

\section{Instrument/sources used to Determine the Misconception in Mathematics}

The studies reviewed have used various sources and instruments to determine students' conceptions in mathematics. It was found that 21 out of the 30 studies reviews used more than one source or instrument, while the remaining studies used only one source. Almost half of the studies used tests such as diagnostic tests, achievement tests and written tests and four studies used diagnostic tests. Two used two-stage diagnostic tests (Lin, 2016; Tabak, 2019) and one study used a four-level test (Yang \& Lin, 2015). Another popular method for determining misconceptions in mathematics is through interviews. These interviews were usually conducted immediately after the test was performed. The interviews conducted, allowed the researcher to better understand the misconceptions demonstrated by the students based on the explanations given.

Two studies also used the instructional plans provided by the students (Kula \& Guzel, 2014; Turnuklu, 2014) while seven studies used questionnaire to obtain information (Gningue, Menil \& Fuchs, 2014; Durkin \& Rittle-Johnson, 2015; Uzel, 2018; Rakes \& Ronau, 2018; Denbel, 2014; Ming et al., 2017; Ang \& Shahrill, 2014). Data were also obtained from document analysis of students' assignments (Makonye \& Faculty, 2016; Dhlamini, \& Kibirige, 2014; Ocal, 2017; Stavrou, 2014; Sisman \& Aksu, 2016), and examination answer scripts (Gningue, Menil \& Fuchs, 2014; Luneta, 2015; Li, Julihi \& Eng, 2017; Ming et al., 2017). This involved the researchers/ teachers analyzing the student's written work to look for patterns and identify possible causes of errors and misconceptions.

\section{Discussion and Conclusion}

This systematic literature review has focused on studies on students' misconceptions in mathematics education. This systematic literature review was carried out based on there is a lack of studies that synthesized students' misconceptions in mathematics. In all, 30 relevant articles were reviewed, and most have focused on determining misconceptions rather than overcoming misconceptions among students. These studies highlighted the challenges in resolving or overcoming misconceptions in mathematics (Uce \& Ceyhan, 2019). This reflects there is a lack of studies that examined the effectiveness of mathematics learning and efforts done to overcome the mathematics misconceptions among students. Therefore, a better approach is to determine the common misconceptions and to identify the common mistakes made by the students. 
The study also found that there is a decrease in the number of articles on misconceptions in mathematics published between 2014 and 2019. This finding contradicts a study conducted by Bulbul and Danisman (2015), who found that there is an increase in the number of mathematical misconceptions studies between 2008 and 2013. In terms of the target participants, most studies reviewed have focused on primary and secondary school students. In the same time, several studies focused on students in higher learning, including university and college students, pre-service teachers, and in-service student teachers. Lee and Ginsburg (2009) mentioned that most studies have focused on what children can do. From a young age, children try to understand their world using specific contexts and meanings. Still, many children would develop misunderstandings about the numerical concepts and operations that may hinder their learning of early mathematical skills. In this regard, in studying mathematics, the misconceptions that students developed during their early schooling will fossilize and create difficulties in learning mathematics at higher levels (Mohyuddin \& Khalil, 2014). The findings of this study show that studies on students' misconceptions could help determine early conceptual misconceptions in mathematics to find possible reasons to better deal with misconceptions in mathematics.

It was also found that some of these articles have focused on similar areas, specifically numbers, fractions, algebra, geometry, and limits. The area of numbers has received the most attention as it is the most basic concept in mathematics education (Lin, 2016), and is extensively taught at the primary level. Furthermore, many students perform poorly in solving algebraic problems involving fractures (Booth, Newton \& Twiss-Garrity, 2014). Therefore, it is not surprising that numbers and fractions are the most widely researched mathematical area.

The majority of the studies reviewed in this study used tests to obtain the data to determine the misconceptions among students. Also, some studies used interviews to determine misconceptions. According to Gurel, Eryılmaz, and McDermott (2015), interviews can help obtain complete and accurate data as it facilitates in-depth communication between the researcher and the study's participant. However, despite the numerous advantages of the interview method, it does take a lot of time to interview the study participants in large numbers. In this regard, it was observed that almost half of the reviewed articles were analyzed using the interview method without regard to time constraints. Therefore, it can be said that the data collected from this study provide significant data to future studies on a misconception.

\section{Recommendation for Future Research}

This study reviewed 30 articles published between 2014 and 2019, which focused on students' misconceptions in mathematics. The review found that most studies are aimed to determine misconceptions; however, the number of studies on how to overcome misconceptions is very limited. Therefore, further studies are proposed to extend the current studies on overcoming misconceptions in mathematics education. Furthermore, studies on misconceptions in mathematics education also need to be carried out at higher levels as most of the studies reviews involved primary and secondary students. Studies have also found teachers are the source of misconceptions among students (Zulnaidi \& Oktavika, 2018). William and Ryan (2000) stated that this could happen when a teacher teaches the wrong concept but does not realize that the concept being taught is wrong. This reflects the need for studies to examine misconceptions among teachers. Also, the review found that studies have used various methods to obtain data and resources to determine misconceptions, but there is no indication of the best method for this process. However, almost half of the studies reviewed have 
INTERNATIONAL JOURNAL OF ACADEMIC RESEARCH IN BUSINESS AND SOCIAL SCIENCES

Vol. 10, No. 6, June, 2020, E-ISSN: 2222-6990 @ 2020 HRMARS

combined different methods and resources to collect data. Therefore, further research could use a variety of methods and data sources to obtain more accurate findings.

\section{Acknowledgement}

This study was funded by Faculty of Education, Universiti Kebangsaan Malaysia grant GG-2019-065

\section{References}

Alghazo, Y. M., \& Alghazo, R. (2017). Exploring common misconceptions and errors about fractions among college students in Saudi Arabia. International Education Studies, 10(4), 133-140. DOI:10.5539/ies.v10n4p133

Aliustaoğlu, F., Tuna, A., \& Biber, A. (2018). The Misconceptions of Sixth Grade Secondary School Students on Fractions. International Electronic Journal Of Elementary Education, 10(5), 591599. Retrieved from https://www.iejee.com/index.php/IEJEE/article/view/512.DOI: 10.26822/iejee.201854130

Ang, L. H., \& Shahrill, M. (2014). Identifying students' specific misconceptions in learning probability. International Journal of Probability and Statistics, 3(2), 23-29.

DOI: 10.5923/j.ijps.20140302.01.

Booth, J. L., Newton, K. J., \& Twiss-Garrity, L. K. (2014). The impact of fraction magnitude knowledge on algebra performance and learning. Journal of Experimental Child Psychology, 118, 110118.DOI: 10.1016/j.jecp.2013.09.001

Brodie, K. (2014). Learning about learner errors in professional learning communities. Educational Studies of Mathematics, 85(2), 221-239. DOI: 10.1007/s10649-013-9507-1

Denbel, D. G. (2014). Students' misconceptions of the limit concept in a first calculus course. Journal of Education and Practice, 5(34), 24-40.

Dhlamini, Z. B., \& Kibirige, I. (2014). Grade 9 learners' errors and misconceptions in addition of fractions. Mediterranean Journal of Social Sciences, 5(8), 236.

DOI: $10.5901 /$ mjss.2014.v5n8p236

Durkin, K., \& Rittle-Johnson, B. (2015). Diagnosing misconceptions: Revealing changing decimal fraction knowledge. Learning and Instruction, 37, 21-29.

DOI: 10.1016/j.learninstruc.2014.08.003

Fadillah, S., \& Susiaty, U. D. (2019). Developing refutation text to resolve students' misconceptions in addition and subtraction of integers. Beta: Jurnal Tadris Matematika, 12(1), 14-25. DOI: $10.20414 /$ betajtm.v12i1.160

Gningue, S. M., Menil, V. C., \& Fuchs, E. (2014). Applying Bruner's theory of representation to teach pre-algebra and algebra concepts to community college students using virtual manipulatives. Electronic Journal of Mathematics \& Technology, 8(3).

Gurel, D. K., Eryılmaz, A., \& McDermott, L. C. (2015). A review and comparison of diagnostic instruments to identify students' misconceptions in science. Eurasia Journal of Mathematics, Science \& Technology Education, 11(5), 989-1008.

https://doi.org/10.12973/eurasia.2015.1369a

Koray, Ö., \& Bal, Ş. (2002). Fen öğretiminde kavram yanılgıları ve kavramsal değişim stratejisi. Gazi Üniversitesi Kastamonu Eğitim Fakültesi Dergisi, 10(1), 83-90. 
INTERNATIONAL JOURNAL OF ACADEMIC RESEARCH IN BUSINESS AND SOCIAL SCIENCES

Vol. 10, No. 6, June, 2020, E-ISSN: 2222-6990 @ 2020 HRMARS

Kula, S., \& Güzel, E. B. (2014). Misconceptions emerging in mathematics student teachers' limit instruction and their reflections. Quality \& Quantity, 48(6), 3355-3372.DOI: 10.1007/s11135013-9961-y

Lee, J. S., \& Ginsburg, H. P. (2009). Early childhood teachers' misconceptions about mathematics education for young children in the united states. Australasian Journal of Early Childhood, 34(4), 37-45. https://doi.org/10.1177/183693910903400406

Li, V. L., Julaihi, N. H., \& Eng, T. H. (2017). Misconceptions and errors in learning integral calculus. Asian Journal of Universiti Education, 13(2), 17-39.

Lin, C. Y., Ko, Y., \& Kuo, Y. C. (2014). Changes in pre-service teachers' algebraic misconceptions by using computer-assisted instruction. International Journal of Technology in Mathematics Education, 21(3), 89101. DOI: 10.1007/978-3-319-45053-7_4

Lin, Y. C. (2016). Diagnosing students' misconceptions in number sense via a web-based two-tier test. Eurasia Journal of Mathematics, Science \& Technology Education, 12(1). https://doi.org/10.12973/eurasia.2016.1420a.

Luneta, K. (2015). Understanding students' misconceptions: An analysis of final grade 12 examination questions in geometry. Pythagoras, 36(1), 1-11. doi:10.4102/pythagoras.v36i1.261.

Machaba, F. M. (2016). The concepts of area and perimeter: insights and misconceptions of grade 10 learners. Pythagoras, 37(1), 1-11. DOI: 10.4102/pythagoras.v37i1.304

Makonye, J. P., \& Fakude, J. (2016). A study of errors and misconceptions in the learning of addition and subtraction of directed numbers in grade 8. SAGE Open, 6(4), 2158244016671375.

Mehmetlioğlu, D. (2014). Misconceptions of elementary school students about comparing decimal numbers. Procedia-Social and Behavioral Sciences, 152, 569-574. doi: 10.1016/j.sbspro.2014.09.245

Ming, C. Y., Eng, C. P., Foong, N. S., \& Ng, K. S. (2017). Undergraduates' error patterns and misconceptions in further differential equations. International Academic Research Journal of Social Science, 3(1), 65-70. DOI: https://doi.org/10.26858/jds.v5i3.4843

Rustam, M. R., \& Azlina, M. K. (2017). Challenges in mathematics learning: A study from school student' s perspective. Research on Educational Study 1. DOI: 10.1016/j.sbspro.2013.10.243

Mohyuddin, R. G., \& Khalil, M. (2014). Misconceptions of students learning in Mathematics at primary level. Bulletin of Education and Research June 2016, Vol. 38, No. 1 pp. 133-162. DOI: 10.11591/ijere.v8.i1.16290 29

Öçal, M. F. (2017). Asymptote misconception on graphing functions: Does graphing software resolve it? Malaysian Online Journal of Educational Technology, 5(1), 21-33. DOI: 10.17220/mojet.

Ozkan, M., \& Bal, A. P. (2017). Analysis of the misconceptions of 7th grade students on polygons and specific quadrilaterals. Eurasian Journal of Educational Research, 16(67). DOI: 10.14689/ejer.2017.67.10

Rakes, C. R., \& Ronau, R. N. (2018). Rethinking mathematics misconceptions: using knowledge structures to explain systematic errors within and across content domains. International Journal of Research in Education and Science, 5(1), 1-21.

Rana, G. M., \& Usman, K. (2016). Misconceptions of students in learning mathematics at primary level. Bulletin of Education and Research. DOI: 10.11591/ijere.v8i1.16290 
INTERNATIONAL JOURNAL OF ACADEMIC RESEARCH IN BUSINESS AND SOCIAL SCIENCES

Vol. 10, No. 6, June, 2020, E-ISSN: 2222-6990 @ 2020 HRMARS

Sarımanoğlu, N. U. (2019). The investigation of middle school students' misconceptions about algebra. Studies in Educational Research and Development, 3(1), 1-22.

Sarwadi, H. R. H., \& Shahrill, M. (2014). Understanding students' mathematical errors and misconceptions: The case of year 11 repeating students. Mathematics Education Trends and Research, 2014(2014), 1-10. DOI: 10.5899/2014/metr-00051

Sisman, G. T., \& Aksu, M. (2016). A study on sixth grade students' misconceptions and errors in spatial measurement: Length, area, and volume. International Journal of Science and Mathematics Education, 14(7), 1293-1319. DOI: 10.1007/s10763-015-9642-5

Smith, J. P., diSessa, A. A., \& Roschelle, J. (1993). Misconceptions reconceived: A constructivist analysis of knowledge in transition. The Journal of Learning Sciences, 3(2), 115-

163. https://doi.org/10.1207/s15327809jls0302_1

Stavrou, S. G. (2014). Common errors and misconceptions in mathematical proving by education undergraduates. Issues in the Undergraduate Mathematics Preparation of School Teachers, 1.

Tabak, S. (2019). 6th, 7th and 8th grade students' misconceptions about the order of operations. International Journal of Educational Methodology, 5(3), 363-373. https://doi.org/10.16949/turkbilmat.333037

Tiwari, C., \& Fatima, R. (2019). Secondary school students' misconceptions in algebra concepts. Mahatma Gandhi Central Universiti Journal of Social, 1(1), 22-33.

Trivena, V., Ningsih, A. R., \& Jupri, A. (2017). Misconception on addition and subtraction of fraction at primary school students in fifth-grade. In Journal of Physics: Conference Series (Vol. 895, No. 1, p. 012139). IOP Publishing.

Türkdoğan, A., Güler, M., Bülbül, B. Ö., \& Danişman, Ş. (2015). Studies about misconceptions in mathematics education in Turkey: A thematic review. Mersin Universiti Journal of the Faculty of Education, 11(2).

Türnüklü, E. (2014). Construction of inclusion relations of quadrilaterals: analysis of pre- service elementary mathematics teachers' lesson plans. Education and Science, 39(173), 197-208. DOI:10.21890/ijres.428968

Üce, M., \& Ceyhan, I. (2019). Misconception in chemistry education and practices to eliminate them: Literature analysis. Journal of Education and Training Studies, 7(3), 202208. https://doi.org/10.11114/jets.v7i3.3990

Üzel, D. (2018). Investigation of misconceptions and errors about division operation in fractions. Universal Journal of Educational Research, 6(11), 2656-2662.

DOI: 10.13189/ujer.2018.061131

Vermeulen, C., \& Meyer, B. (2017). The equal sign: teachers' knowledge and students' misconceptions. African Journal of Research in Mathematics, Science and Technology Education, 21(2), 136-147. DOI: 10.1080/18117295.2017.1321343

Williams, J., \& Ryan, J. (2000). National testing and the improvement of classroom teaching: Can they coexist? British Educational Research Journal, 26(1), 49-73. DOI: 10.1080/014119200109516

Winarso, W. (2017). a case study of misconceptions students in the learning of mathematics; the concept limit function in high school. Jurnal Riset Pendidikan Matematika, 4.

Yang, D. C., \& Lin, Y. C. (2015). Assessing 10-To 11-year-old children's performance and misconceptions in number sense using a four-tier diagnostic test. Educational Research, 57(4), 368-388. DOI: 10.1080/00131881.2015.1085235 
INTERNATIONAL JOURNAL OF ACADEMIC RESEARCH IN BUSINESS AND SOCIAL SCIENCES

Vol. 10, No. 6, June, 2020, E-ISSN: 2222-6990 @ 2020 HRMARS

Zulnaidi, H., \& Oktavika, E. (2018). The effect of geogebra on students' misconceptions of limit function topic. JuKu: Jurnal Kurikulum \& Pengajaran Asia Pasifik, 6(1), 1-6. 